\title{
Examining the Effect of Cultural Intelligence on the Internationalization of Swiss Small and Medium Enterprises
}

\author{
Hadia Fakhreldin ${ }^{1}$ \\ ${ }^{1}$ Faculty of Business, Economics and Political Science, The British University, Egypt \\ Correspondence: Hadia Fakhreldin, Faculty of Business, Economics and Political Science, The British University, \\ Egypt.
}

Received: April 6, 2018

doi:10.5539/ibr.v11n6p89
Accepted: May 10, $2018 \quad$ Online Published: May 18, 2018

URL: https://doi.org/10.5539/ibr.v11n6p89

\begin{abstract}
The study examines the relationship between cultural intelligence (CI) and the internationalization of Swiss Small and Medium Enterprises (SMEs). It also evaluates the role of internationalization motivators within that relationship. A self-administered survey was sent (by email) to the managers of 640 Swiss SMEs, identified from the Swiss SME database (Switzerland Global Enterprises-ge.com). The data analysis confirms that the internationalization process and the intention to internationalize depend to a large extent on the cultural intelligence of these managers. The analysis also identified access to information on foreign markets as the main motivator that affects this relationship. The study proposes solutions and recommendations to stakeholders and policy makers to enhance and support SME internationalization through developing specific individual and organizational aspects, mainly the cultural competencies of managers and more access to detailed information on foreign markets and their differing environments.
\end{abstract}

Keywords: cultural intelligence, internationalization, motivators to internationalize, Small and Medium Enterprises (SMEs), Switzerland

JEL: M16, M13

\section{Introduction}

One of the outcomes of globalization is that companies and countries are increasingly dealing with the forces of internationalization in all economic spheres; public and private. This is evident in developing and developed countries. SMEs should be in a better position when it comes to internationalization, as they can better respond to changing market conditions, evolving consumer preferences and shorter product life cycles by customizing and differentiating products (OECD P. A., 2000). This means that a country like Switzerland, whose economy relies on SMEs for growth and development, should have a clear advantage (OECD, 2004). Swiss SMEs are increasingly internationalizing to compete with the advantages and dominance of large international companies stemming from the forces of globalization. However, many are struggling, and the pace of internationalization is slower than they desire. In 2015 the percentage of the revenues of SMEs stemming from exports was around 57\% (Baldegger, R., Wild, P., Morel, B., 2016).

The literature identifies various difficulties that generally face SMEs targeting international markets. These range from obstacles at the level of the individual (manager/entrepreneur) - which stem from the internal environment - to impediments at the organizational level - which largely result from the external environment. The OECD report on Small and Medium-sized Enterprises emphasized that SMEs need to upgrade their management skills, their capacity to gather information and their technology base (OECD P. A., 2000) - not in refs! to be able to enter foreign markets. Internationalization would also require their governments to improve the access to financing, information infrastructures and international markets (OECD P. A., 2000) not in refs. Therefore, both the individual and the organizational aspects play a key role in SME international expansion.

This study examines the relation between individual attributes and internationalization. It analyses the different dimensions of cultural intelligence and explores how these dimensions contribute to the initiation and/or success of the internationalization of Swiss SMEs. Furthermore, it examines the organizational motivators/obstacles and considers them as environmental factors (internal and external). It attempts to identify those that are most important and whose absence may hinder internationalization the most. The paper is organized as follows: 


\section{Literature Review}

\subsection{Cultural Intelligence}

Cultural intelligence is an important concept because of its positive influence on international business success (Crowne, 2008). It is one of related conceptualizations (e.g. cultural adaptability, intercultural competence and sensitivity) which are products of the interaction of various fields of research: sociology, psychology, management, organizational behavior and anthropology. They all refer to a person's motivation and skills as well as his/her behavior and strategies for dealing with people and situations influenced by cultures different from his/her own dominant culture (Fakhreldin, 2011).

A widely accepted definition of cultural intelligence (CI) is the one by Ang et al., it refers to "an individual's capability to function effectively across cultures" (Ang, Livermore, \& Van Dyne, 2010) (Mor, Morris, \& Joh, 2013). This means that CI refers to the ability to perform effectively in situations and surroundings different to those one has been used to. Being culturally intelligent means identifying behaviors that are universal, behaviors that are cultural and distinguish other behaviors that are idiosyncratically personal to an individual in a specific situation (Van Dyne et al., 2010). CI should not be confused with 'cultural adaptation', as it goes beyond this (NG \& Earley, 2006). Cross cultural adaptation refers to four skills only; emotional resilience, flexibility, perceptual acuity and personal autonomy. They are all fundamental for effective and appropriate cross-cultural management (Spencer-Oatey \& Franklin, 2010). CI covers more aspects and entails the skills of cross-cultural adaptability in addition to knowledge, motivation and behavior (Ang \& Inkpen, 2008). According to Ang et al. (2010), CI focuses specifically on one's capability to effectively understand and adapt to a myriad of cultural contexts as an essential skill set needed to operate and/or lead effectively across cultures.

The CI (numerically referred to as Cultural Quotient - CQ) consists of the sum of 4 quotients reflecting 4 components (motivational, cognitive, metacognitive and behavioral). The motivational CQ describes desire and self-efficacy (NG \& Earley, 2006), in situations characterized by cultural differences (NG, Dyne, \& Ang, 2009). Cognitive CQ refers to knowledge about different cultures (NG \& Earley, 2006), as well as awareness of different cultural settings acquired from education and personal experience (NG et al., 2009). Metacognitive CQ is concerned with the cognitive strategies to acquire and develop coping strategies (NG \& Earley, 2006), especially in intercultural interaction (NG et al., 2009). It is argued that this dimension is the core of CI (Mor et al., 2013). Behavioral CQ describes the repertoire of culturally appropriate behaviors, words and gestures (NG \& Earley, 2006), in cross-cultural interactions (NG et al., 2009). This four-factor model of CI has the support of different scholars and researchers (Fakhreldin, 2011; Ang et al., 2010; Crowne, 2008).

There were several attempts to develop models and introduce scales to determine and measure CI. The CQ (Cultural Quotient) by Earley and Ang (2003) was shown to be both valid and reliable in different studies conducted by various scholars (FakhrEldin, 2011; Ang \& Inkpen, 2008; Van Dyne et al., 2008; Ang, et al., 2007;). It consists of statements covering each of the four dimensions, which are evaluated through a Likert scale. The sum of these scores describes the individual's capability to function and manage effectively in culturally diverse settings (Ang, et al., 2007).

\subsection{Internationalization}

Internationalization takes place when enterprises cross their national borders entering different countries to offer their products/services to diverse markets (Masum \& Fernandez, 2008). Therefore, internationalization is the process in which firms expand their activities abroad and increase their foreign market involvement (APEC as cited in Yuhua) (2015). This notion of expansion and increase of activities is reflected in the various definitions adopted by scholars to define internationalization.

The OECD adopts a broad definition and describes it as business expansion and growth in international markets (Kalinic \& Forza, 2012). Johansson and Vahle's definition is comprehensive and is adopted in many academic studies; it is the on-going process of increasing the business's dedication and contribution in the international market arena (Mura, 2011). However, this does not necessarily mean that all firms will succeed in this endeavour. The process is dynamic and is initiated and supported by specific motivations and it is affected by many variables (Wild, 2014). Furthermore, there are specific patterns that firms follow to expand beyond their borders (Lloyd-Reason et al., 2009). Several theories and approaches have examined these stages starting from the Uppsala model (which is resource-based) to the market model which is behavioraly based to the network model which draws on theories of social exchange (Kamakura, Ramón-Jerónimo, \& Gravel, 2012). Although these theories are based on different approaches, they all examine and highlight the motivation to internationalize and try to evaluate and explain the forces that drive this motivation. Nevertheless, there is no 
concrete conclusion regarding the order of importance of these factors when it comes to internationalization intention or implementation.

One of the main motivations for internationalization is advancement and development in technological and economic spheres on a global level and the increase in volume and value of international trade (Wambui, 2013), which is (hoped) will result. Also, the lowering of barriers to trade has made international markets more accessible; it also created push and pull factors (Doole \& Lowe, 2008). These two motivations combine the traditional and the modern view, the former is concerned with securing basic sources and raw materials, using technological advancements and gaining competitive advantage (Wambui, 2013). The latter advocates that firms internationalize to achieve social and economic developments which are essential for businesses to survive (Acs $\&$ Terjesen, 2013). There is also agreement in the literature - regardless of the theoretical approach - that human capital, technology, and managerial ties overseas appear as key factors in the international evolution of businesses (Kamakura, Ramón-Jerónimo, \& Gravel, 2012).

Much of the literature on firms' internationalization initially focused on the exporting mode of entry. Traditionally, this is the major internationalization strategy which increases firms' international expansion (Masum \& Fernandez, 2008). However, in the current decade and certainly since 2001 the focus (of the firms and consequently the literature - has been shifting to different internationalization entry mode strategies (Doole $\&$ Lowe, 2008). These include licensing, franchising, joint venture and foreign direct investment (FDI) (Wild, 2014). The advancement in technology - and within it the increasing role of the social media - made many modes of entry more accessible and less resource-consuming to initiate and monitor.

\subsection{Small and Medium Enterprises (SMEs)}

The European Commission defines SMEs as the category of micro, small and medium-sized enterprises (SMEs) that are made up of entities which employ fewer than 250 persons and which have an annual turnover not exceeding 50 million euros, and/or an annual balance sheet total not exceeding 43 million euros (Masum \& Fernandez, 2008). The OECD adds that SMEs are diverse groups operating in different business activities and markets (OECD, 2004).

Omer et al. (2015) indicate that SMEs constitute the backbone of any country's economy, they create job opportunities, improve the economy and promote the effective use of regional resources which leads to economic growth and development (2015). Despite this significant role in the economy, SMEs face serious constraints in many countries, often resulting in their failure (Sha, 2006). One strategy that can be used to overcome local constraints is internationalization (Udomkit \& Schreier, 2015).

\subsection{Internationalization of SMEs}

Since the middle of the twentieth century, the world has witnessed a rapid internationalization of markets, industries and firms, which led to an increased number of conceptual and empirical studies on international entrepreneurship (Moen \& Servais, 2002). Although gradual internationalization models have been criticized for being too deterministic, the field of born-global research (SMEs that start as international entities from inception) has been largely fragmented and has provided different theoretical and methodological approaches (McDougall and Oviatt 2000).

Internationalization has become increasingly important to the competitiveness of enterprises of all sizes (Wilson, 2006). It is also significant in the case of SMEs, as they cannot always depend on the national or even local market. Despite the considerable research on the internationalization of SMEs in recent years, no comprehensive framework has yet emerged to explain and predict the factors leading to SMEs going global. SME internationalization is described as the process used by an SME to approach new markets and customers, to have access to specific resources, materials or a more expertise workforce; to protect its products from domestic competition as well as to extend and leverage its business capability internationally (Onkelinx \& Sleuwaegen, 2008). Although many theoretical frameworks exist to explain internationalization the subject field still poses a critical challenge, particularly in relation to SMEs (Moen 2002).

There are several forms of SME internationalization, most typically it is exporting (Masum \& Fernandez, 2008); however, firms now focus on diverse activities, such as partnering with foreign firms to develop a strong international business through knowledge and technology exchange/transfer (Kalinic \& Forza, 2012). SMEs seek to internationalize to alleviate risk and to generate profit that can be further utilised to enhance research and development and expansion of operations (Yuhua, 2015). As stated by the APEC Policy Support Unit, internationalization helps in alleviating SMEs risk through being in diverse markets, generating more profits to be invested in production and technological advancements that are acquired when dealing with foreign markets. 
Also, it helps in improving the efficiency of SMEs. SMEs, which do internationalize, are able to develop more than SMEs focusing only on local markets (Lakew \& Chiloane-Tsoka, 2015).

The classical drivers for SMEs to internationalize are stemming from the external environment; economic, technological and political reasons, as well as globalization that helps such firms to find different opportunities (Masum \& Fernandez, 2008). Czinkota (2002) proposed dividing these forces in terms of reactive and proactive reasons for an SME to internationalize. The proactive motives offer an incentive to change the strategy of the firm based on its interest in developing unique skills and market capabilities. These motives are profit benefit, technological advantage, managerial support, economies of scale and scope, access to resources and information, opportunities to grow and saving costs (OECD, 2004). On the other hand, the reactive motives indicate that firms internationalize due to pressures from local markets, e.g. overproduction, surplus capacity, competitive pressure, decline in local sales, proximity to new customers and saturation (London, 2010).

There are also barriers that impede the process of internationalisation for SMEs. Some of these are stemming from the external environment, but they are mostly internally (individually) driven. In general, SMEs - by nature - have limited resources (Udomkit \& Schreier, 2015; Acs \& Terjesen, 2013). This is the case with respect to physical resources as well as financial and human resources. The same applies to other factors, e.g. lack of internationalization experts, scarce information about overseas markets, especially in meeting international product standards rules are a serious barrier for some SMEs (OECD, 2009). Furthermore, the inability of local SMEs to recognize an international opportunity, failure in contacting customers and unfamiliarity in the international procedures for SMEs are barriers that impede SME internationalization (OECD, 2009). The latter demonstrates deficiencies in the competencies of the leaders and owners of the SMEs; this includes management capabilities, intercultural competencies, knowledge and relevant past experiences (Udomkit \& Schreier, 2015). Thus, knowledge of foreign markets and the ability to reach and communicate with different customers in different parts of the world are important factors that affect the ability to internationalize. The Swiss International Entrepreneurship Survey of 2016 identified "international entrepreneurial orientation" (IEO), as a key factor influencing the degree and the success of internationalization of SMEs (Baldegger et Al., 2016, p. 19). The IEO is a facet of CI, as it describes the attitude of the company and its managers towards opportunities and involvement in international markets (more or less the behavioral component of CI).

The APEC stated that the internationalization of SMEs is hard to measure, as there is no single body keeping records of their activities (Yuhua, 2015). Therefore, the figures from secondary data are not accurate, as they do not represent all SMEs operating; many are not formalized and do not have records. Several attempts have been made to rectify this however, they were not successful due to poor or scarce SME records themselves. Hence, most researchers in this field use the Survey approach or the Census approach (Yuhua, 2015). However, it is not clear in the literature, which factors are more important in achieving and maintaining SME internationalization.

With respect to SME internationalization entry modes, SME's tend mostly to adopt classic foreign market entry strategies. This includes licensing, franchising, joint ventures as well as mergers and acquisitions (Foreman-Peck $\&$ Zhou, 2015). FDI provides SMEs with entire ownership and full control of operations, but it can be costly and requires high commitment with high uncertainty and risk in the host market (Jakl \& Volery, 2006). Deciding on the internationalization strategy and the entry mode strategy depends on many aspects; SMEs current state -, i.e. knowledge of foreign markets, past experiences, accessibility to resources, communication skills, networking, degree of control and commitment, stability, risk involvement and the structure of the targeted market in the foreign country (Gunnarsson, 2011). Therefore, the motivators of and the obstacles to internationalization, on both the individual and the organizational levels, are all determinants of SMEs expansion potential.

\subsection{Swiss SMEs}

Swiss SMEs are more than 300000 in number and they constitute 95\% of the Swiss economy (Zhu et al., 2012). According to the GEM (Global Entrepreneurship Monitor) report, Switzerland's entrepreneurial orientation is higher than the European average (Kelley, Singer, \& Herrington, 2012) and (Kelley et al., 2012). Switzerland is characterized by the success of its SMEs; it has been able to secure its top position in the field of innovation consistently) (Eidgenossenschaft, 2017). Switzerland continues to hold the top position in the Global Competitiveness Ranking of the World Economic Forum (Acs, Szerb, \& Autio, 2016). In addition, Switzerland successfully secured its top position in the current Global Innovation Index, which is published jointly by Cornell University, INSEAD and the UN (Dutta, Lanvin, \& Wunsch-Vincent, 2015).

Nevertheless, it is not easy for the Swiss SMEs despite their advancement and success in innovation to expand into international markets. Swiss SMEs face a problem of shortage of human resources, specifically in the area internationalization (Jakl \& Volery, 2006). It is reported that there is a considerable difficulty in finding 
employees who are willing and capable of doing business internationally (Udomkit \& Schreier, 2015). Furthermore, research has shown that Swiss SMEs identified intercultural experience as the most important factor in internationalization efforts, where $90 \%$ of the respondents of the survey conducted (among 309 Swiss SMEs) confirmed that "intercultural competences help internationalize businesses" (Udomkit \& Schreier, 2015, p. 33).

Based on the above, the study proposes a conceptual model which is focusing on the cultural intelligence attributes of the individuals in the SME and how they affect internationalization. The model integrates the resource-based view with the behavioral and the network view by considering the main variables identified (and empirically confirmed in the literature) in each and organizing them as "motivators to internationalize". These are: differential firm advantages, networks, production capacity, unsold inventory, additional orders, foreign country regulations, foreign market information, increased competition, value chain advantages, export promotion programs, growth opportunities, unsolicited orders (Crick, 2007).

These motivators should also affect this relation, as they are agreed-upon drivers of internationalization.

\section{Conceptual Model}

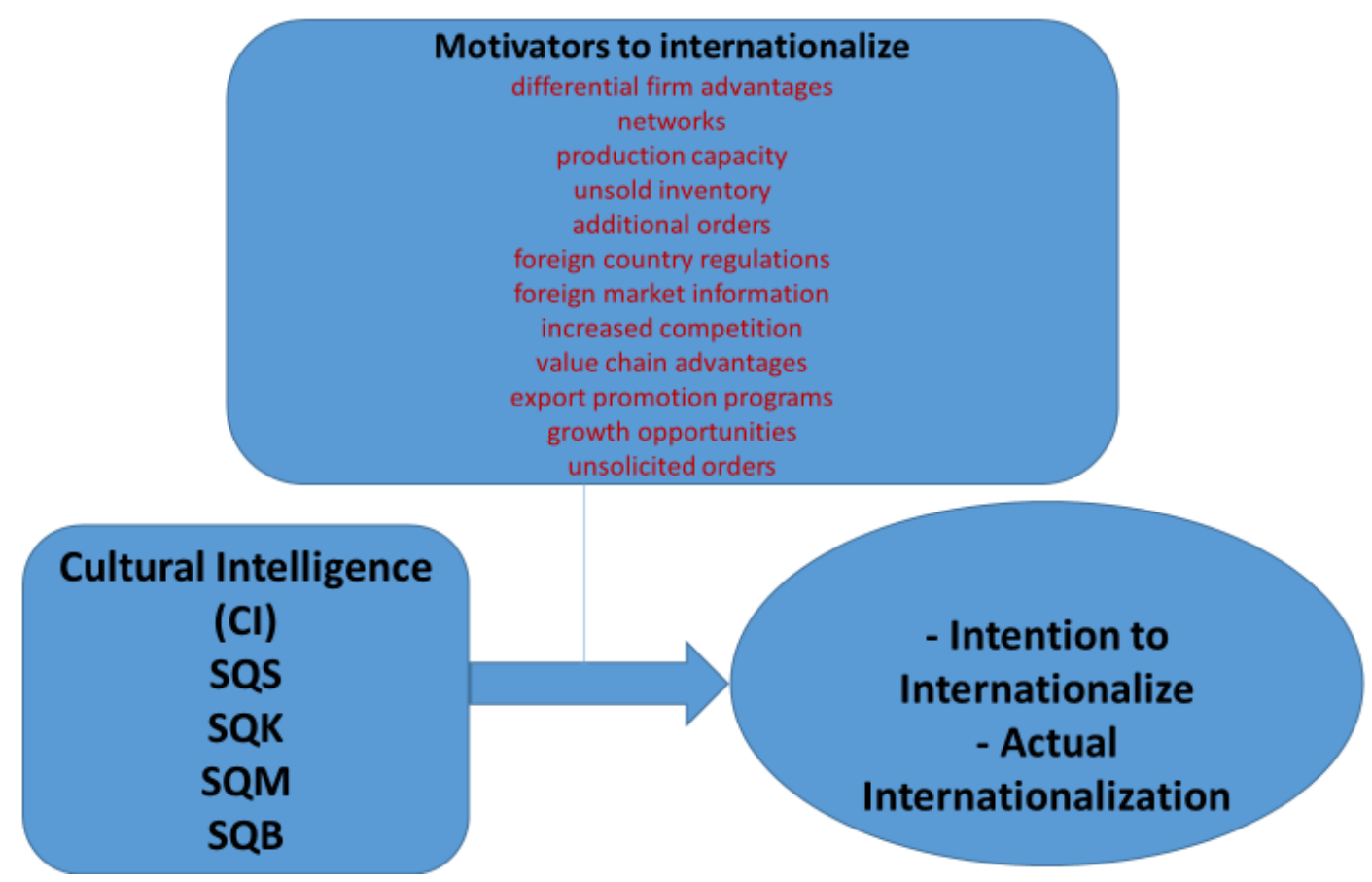

Figure 1. The Impact of Cultural Intelligence on SME Internationalization (author's own work)

Using the above conceptualisation, research questions and hypotheses can be derived as below:

\section{Research Questions and Hypotheses}

The study attempts to answer the following research questions to fill the gaps in the literature:

1. To what extent does Cultural Intelligence affect both the intention to internationalize and the actual internationalization of Swiss SMEs?

2. How do the internationalization motivators stemming from the internal and external environment affect the relationship between Cultural Intelligence and SME Internationalization in Switzerland?

The study tests the following hypotheses using the data collected in Switzerland in the context of the model represented in Figure (1):

H1: There is a significant relation between Cultural Intelligence and SME Internationalization intention in Switzerland.

$\mathrm{H} 2$ : There is a significant relation between Cultural Intelligence and actual SME Internationalization in Switzerland.

H3: There is a significant relation between each dimension of Cultural Intelligence and the internationalization intention of SMEs in Switzerland. 
H4: There is a significant relation between each dimension of Cultural Intelligence and the actual internationalization of SMEs in Switzerland.

H5: The Relationship between Cultural Intelligence and SME Internationalization intention is affected by the internationalization motivators in the internal and the external environments of the SMEs in Switzerland.

H6: The Relationship between Cultural Intelligence and actual SME Internationalization is affected by the internationalization motivators in the internal and the external environments of the SMEs in Switzerland.

\section{Methodology and Research Design}

The study uses a mixed method of quantitative and qualitative strategies. The data gathered and analysed usually give accurate statistical results that can be further verified using the personal interview approach (McCusker \& Gunaydin, 2014).

\subsection{Sample Characteristics}

There are more than 300000 SMEs in Switzerland. Privacy is important for the Swiss and it is practically impossible to reach someone's name and contacts, if one does not already know this person. The telephone number provided in any listing was a general one that directs you to someone who only receives and transfers messages. The email contacts lead to a general inquiry form to be filled out, then a clerk from the company responds to the query. Both methods have been tried through a sample of 50 company contacts in each method. The general inquiry form did not result in any information, whereas the phone calls resulted in obtaining 8 contact names and emails.

This enabled conducting preliminary interviews with 8 SME managers who also reviewed the initial survey. Each manager also recommended certain databases to use for identifying the sample and distributing the survey. They all agreed on using the database of Switzerland Global Enterprise and the yellow pages.

\subsection{Data Collection Procedure}

A pilot was undertaken through conducting interviews with 8 Swiss SME managers to confirm the findings of the literature and test and update the survey instrument. The main revision suggested by one of the managers was to translate the survey to German. This was surprising, as the assumption of the researcher was that it was logical to have the survey in English, as this is the international business language. After the other 7 managers were consulted, it was agreed to convert the survey to the German language. However, they agreed that both versions should be sent out and the respondents would choose which one to complete.

All suggested revisions from the pilot study were made and the survey was translated and back-translated to ensure accuracy. It was sent by email to more than 600 Swiss SMEs, as identified from the Swiss SME database (Switzerland Global Enterprises-ge.com). They were identified based on activities that are significant in Switzerland: chemicals, mechanical? manufacturing, textiles, pharmaceuticals, technology and accessories (e.g. shoes, watches).

A total of 102 questionnaires were returned, out of which 98 were valid ( 8 were from the pilot study and were reached through phone and then visited in person). There were 7 responses by email stating that they are not interested to do the survey. Two said they did not have the time and one said she was on vacation and could do it after 5 weeks. Interestingly, all these apology responses were from female managers/entrepreneurs. The total response rate is $17 \%$, which is acceptable. Excluding the 8 of the pilot, this resulted in a $15 \%$ valid response rate which is acceptable in email or on-line surveys. As Adams et al $(2014$, p.131) argue "... response rates from surveys - whether postal, telephonic or electronic — are rarely higher than 20 per cent." Therefore, a 15 percent valid response rate in this research is considered very good.

The characteristics of the valid sample responses are as follows:

Most of the respondents are males (93\%), where $80 \%$ are University graduates, $15 \%$ have only a high school degree and $5 \%$ have a doctorate degree. With respect to specialization, half of the sample are specialized in Business or Economics, while $45 \%$ are Engineers. The sample has a representative distribution when it comes to the size of the enterprise; around $45 \%$ have less than 50 employees, $25 \%$ have between 50 and 250, and 20\% have between 250 and 500 employees. Half of the enterprises are in the manufacturing industries and most of the other half are service providers. 


\subsection{Method}

The Cultural Intelligence Scale (CQS) developed by Earley and Ang is used to measure CI of individuals; it is adopted by the author and consists of 22 items; it assesses 3 items for metacognitive CQ, seven for cognitive CQ, six for motivational CQ and six for behavioural CQ. As it is a self-rating scale, taking this test means giving oneself a mark from $1-7$ on each of the items. One of the items was reversed to make sure that respondents are focusing while taking the survey. It is the last question in the motivational CQ. This score was then reversed when adding the total scores of SQ. This part of the survey is followed by questions regarding the motivation for SME internationalization to identify which ones are more effective in the internationalization initiation and continuation. The reliability of the scale was tested, and it proved reliable with a Cronbach alpha score of 0.88 . Each of the sub-constructs also proved reliable with a Cronbach alpha score of above 0.77 (McCusker \& Gunaydin, 2014).

There are 3 questions regarding the internationalization itself: action, intention and number of years. The remaining questions elicited biographical information.

\section{Findings and Discussion}

The statistical analysis is conducted using SPSS. The number of cases examined was 98 , after eliminating invalid responses. First, Pearson correlation is calculated taking into consideration the variables. The correlation matrix is presented in Table 1 below.

Table 1. Correlation Matrix

\begin{tabular}{|c|c|c|c|c|c|c|c|c|c|}
\hline Correlation Matrix & & Internationalization & $\begin{array}{c}\text { No. of years } \\
\text { internationalized }\end{array}$ & $\begin{array}{c}\text { intention to } \\
\text { internationalize }\end{array}$ & SQS & SQK & SQM & SQB & SQ \\
\hline \multirow[t]{2}{*}{$\begin{array}{l}\text { International- } \\
\text { alization }\end{array}$} & $\begin{array}{l}\text { Pearson } \\
\text { Correlation }\end{array}$ & 1 & $1.000^{* *}$ & $1.000^{* *}$ & $-.348^{* *}$ & $-.224^{*}$ & $-.291^{* *}$ & .019 & $-.234^{*}$ \\
\hline & $\begin{array}{l}\text { Sig. } \\
\text { (2-tailed) }\end{array}$ & & 0.000 & 0.000 & .000 & .027 & .004 & .853 & .020 \\
\hline \multirow[t]{2}{*}{$\begin{array}{l}\text { number of years } \\
\text { internationalized }\end{array}$} & $\begin{array}{l}\text { Pearson } \\
\text { Correlation }\end{array}$ & & 1 &.$^{\mathrm{a}}$ & $.203^{*}$ & -.031 & .049 & .195 & .109 \\
\hline & $\begin{array}{l}\text { Sig. } \\
\text { (2-tailed) }\end{array}$ & & & 0.000 & .049 & .762 & .639 & .058 & .293 \\
\hline \multirow[t]{2}{*}{$\begin{array}{l}\text { intention to } \\
\text { internationalize }\end{array}$} & $\begin{array}{l}\text { Pearson } \\
\text { Correlation }\end{array}$ & & & 1 & $-.348^{* *}$ & $-.224^{*}$ & $-.291^{* *}$ & .019 & $-.234^{*}$ \\
\hline & $\begin{array}{l}\text { Sig. } \\
\text { (2-tailed) }\end{array}$ & & & & .000 & .027 & .004 & .853 & .020 \\
\hline \multirow[t]{2}{*}{ SQS } & $\begin{array}{l}\text { Pearson } \\
\text { Correlation }\end{array}$ & & & & 1 & $.435^{* *}$ & $.677^{* *}$ & $.349^{* *}$ & $.688^{* *}$ \\
\hline & $\begin{array}{l}\text { Sig. } \\
\text { (2-tailed) }\end{array}$ & & & & & .000 & .000 & .000 & .000 \\
\hline \multirow[t]{2}{*}{ SQK } & $\begin{array}{l}\text { Pearson } \\
\text { Correlation }\end{array}$ & & & & & 1 & $.626^{* *}$ & $.531^{* *}$ & $.884^{* *}$ \\
\hline & $\begin{array}{l}\text { Sig. } \\
\text { (2-tailed) }\end{array}$ & & & & & & .000 & .000 & .000 \\
\hline \multirow[t]{2}{*}{ SQM } & $\begin{array}{l}\text { Pearson } \\
\text { Correlation }\end{array}$ & & & & & & 1 & $.290^{* * *}$ & $.780^{* *}$ \\
\hline & $\begin{array}{l}\text { Sig. } \\
\text { (2-tailed) }\end{array}$ & & & & & & & .004 & .000 \\
\hline \multirow[t]{2}{*}{ SQB } & $\begin{array}{l}\text { Pearson } \\
\text { Correlation }\end{array}$ & & & & & & & 1 & $.744^{* *}$ \\
\hline & $\begin{array}{l}\text { Sig. } \\
\text { (2-tailed) }\end{array}$ & & & & & & & & .000 \\
\hline SQ & $\begin{array}{l}\text { Pearson } \\
\text { Correlation } \\
\text { Sig. } \\
\text { (2-tailed) }\end{array}$ & & & & & & & & 1 \\
\hline
\end{tabular}

The research's dependent variables are the internationalization intention and internationalization success, which are categorical. Therefore, logistic regression is used to predict the contribution of each independent variable to the probability of the occurrence of the dependent variable. A series of logistic regressions are conducted to cover all the possible relationships between the independent (CQ with all its constructs/dimensions; SQS, SQK, $\mathrm{SQM}, \mathrm{SQB}$ ) and the dependent variables (internationalization intention, internationalization action, internationalization years). In addition, age, as well as the internal and external internationalization motivations were considered. 
Table 2. Results of Logistic Regression

Internationalization intention as a dependent variable and all independent variables

\begin{tabular}{lccc}
\hline & Wald statistic & Sig & Decision \\
\hline SQS & 6.975 & 0.008 & Significant \\
SQK & 3.873 & 0.049 & Significant \\
SQM & 5.507 & 0.019 & Significant \\
SQB & 0.035 & 0.98 & Not Significant \\
SQ & 3.938 & 0.047 & Significant \\
Education & 0.0 & 1 & Not Significant \\
Specialization & 1.67 & 0.196 & Not Significant \\
Work years & 0.0 & 1 & Not Significant \\
Size & 0.0 & 1 & Not Significant \\
Age & 0.025 & 0.875 & Not Significant \\
Differential Firm Advantages & 1.24 & Not Significant \\
Networks & 1.532 & 0.265 & Not Significant \\
Production Capacity & 2.611 & 0.216 & Not Significant \\
Unsold Inventory & 0.6 & 0.106 & Not Significant \\
Additional Orders & 0.209 & 0.438 & Not Significant \\
Foreign Country Regulations & 0.612 & 0.647 & Not Significant \\
Foreign Market Information & 4.7 & Significant \\
Increased Competition & 0.674 & 0.434 & Not Significant \\
Value Chain Advantages & 0.475 & 0.03 & Not Significant \\
Export Promotion Programs & 0.377 & 0.412 & Not Significant \\
Growth Opportunities & 0.618 & 0.491 & Not Significant \\
Unsolicited Orders & 0.338 & 0.539 & Not Significant \\
\hline
\end{tabular}

The CI as a construct is significant. Looking at the individual components, we find the metacognitive SQS is most significant. The Behavioral SQ is not significant. When it comes to the motivators, there is only one aspect that is significant: the access to market information, which is proposed in the literature (Udomkit \& Schreier, 2015; Acs \& Terjesen, 2013; OECD, 2009). This is remarkable, but it is logical. When a firm intends to internationalize, the fundamental requirement it needs is accurate and comprehensive information about the market it wants to pursue. Otherwise, it would be operating in the dark and taking a risk for no obvious gains.

Table 3. Results of Logistic Regression

Actual internationalization as a dependent variable and all independent variables

\begin{tabular}{lccc}
\hline & Wald statistic & Sig & Decision \\
\hline SQS & 6.975 & 0.008 & Significant \\
SQK & 3.87 & 0.048 & Significant \\
SQM & 5.507 & 0.019 & Significant \\
SQB & 0.035 & 0.98 & Not Significant \\
SQ & 3.938 & 0.047 & Significant \\
Education & 0.0 & 1 & Not Significant \\
Specialization & 1.67 & 0.196 & Not Significant \\
Work years & 0.0 & 1 & Not Significant \\
Size & 0.0 & 1 & Not Significant \\
Age & 31.104 & 0.0 & Significant \\
Differential Firm Advantages & 23.2 & 0.0 & Significant \\
Networks & 25.5 & 0.0 & Significant \\
Production Capacity & 22.3 & 0.0 & Significant \\
Unsold Inventory & 21.5 & 0.0 & Significant \\
Additional Orders & 26.6 & 0.0 & Significant \\
Foreign Country Regulations & 29.8 & 0.0 & Significant \\
Foreign Market Information & 24.1 & 0.0 & Significant \\
Increased Competition & 29.8 & 0.0 & Significant \\
Value Chain Advantages & 28.8 & 0.0 & Significant \\
Export Promotion Programs & 27.3 & 0.0 & Significant \\
Growth Opportunities & 30.4 & 0.0 & Significant \\
Unsolicited Orders & 26.1 & 0.0 & Significant \\
\hline
\end{tabular}

The CI measured by the cultural quotient has a significant effect on the actual internationalization. All dimensions of SQ are significant, except the behavioral SQB. This means, that the culturally appropriate behavior, words and gestures are not of high importance; it is rather the strategy, the self-efficacy, the desire and the knowledge that are more important in the internationalization context. The highest significance is in the meta-cognitive dimension, which is viewed as the core of cultural intelligence (Mor et al., 2013).

It is interesting to note, that all the motivators are of high importance as they affect the relationship between CI 
and actual internationalization positively and significantly. Therefore, they can be considered as ongoing reasons for the continuous success of the internationalization. This implies, that even if they were not the initial reason for internationalization, they are important to continue and maintain the internationalization momentum of the SMEs. After the firm is already international, it pursues sustaining this condition which is achieved by taking all options/drivers of internationalization into account.

Based on the analysis, the following can be concluded:

1. Cultural Intelligence affects the internationalization of SMEs to a high extent. It is important for SME managers and owners to possess $\mathrm{CI}$, to be ready to consider internationalisation and then engage successfully in it.

2. The internationalization motivators stemming from the internal and external environment play a significant role in already internationalized SMEs. However, when it comes to the intention to internationalize, a major contributor to this initiative is the access to foreign market information. This is the one aspect, that needs to be fulfilled in order to pursue the engagement in global markets.

With respect to the hypothesis, the following is concluded:

H1: There is a significant relation between Cultural Intelligence and SME Internationalization intention in Switzerland.

$\mathrm{H} 2$ : There is a significant relation between Cultural Intelligence and SME actual Internationalization in Switzerland.

H3: There is a significant relation between each dimension of Cultural Intelligence and the internationalization intention of SMEs in Switzerland. This is partially accepted, as the behavioral dimension of the $\mathrm{CI}$ is not significant in the relation.

H4: There is a significant relation between each dimension of Cultural Intelligence and the actual internationalization of SMEs in Switzerland. This is partially accepted, as the behavioral dimension of the $\mathrm{CI}$ is not significant in the relation.

H5: The Relationship between Cultural Intelligence and SME Internationalization intention is affected by the internationalization motivators in the internal and the external environments of the SMEs in Switzerland. This is confirmed on a limited scale, only with the access of market information.

H6: The Relationship between Cultural Intelligence and SME actual Internationalization is affected by the internationalization motivators in the internal and the external environments of the SMEs in Switzerland. This is accepted.

\section{Conclusion and Recommendations}

The study confirms that the internationalization intention and the actual internationalization are supported by the cultural intelligence of the managers/owners of the SMEs. Furthermore, access to information of foreign markets is identified as the main contributor to pursuing internationalization. This means that a main barrier to initiate and engage in internationalization is the lack of access to sufficient information about international markets.

Therefore, governments, policy-makers and stakeholders should focus on developing more effective tools and processes to provide the Swiss SMEs with accurate and sufficient data and information about foreign markets. In addition, Swiss SMEs should enhance the capabilities of their employees with the skills and attributes associated with Cultural Intelligence. Special attention should be given to developing the metacognitive strategizing skills and the motivational and cognitive attributes. This can be achieved through training the existing employees (Mor et al., 2013). It can also be attained through the careful selection and recruitment of employees who have international experience, knowledge and inter-cultural competency (Barmeyer \& Frankilin, 2016).

One of the limitations of this study is that the responses received mainly reflect the status of SMEs which are interested in internationalization. Therefore, the results do not represent all SMEs. Future studies should try to reach more SME managers. There should be an attempt to reach managers who are not pursuing internationalization and try to examine the motivations and or obstacles leading to this condition. More in-depth interviews and personal meetings while filling out the surveys will enrich the results, as more details can be added, that complement other perspectives.

Another limitation is the tendency towards emphasizing elements of the resource-based view in the conceptual framework and consequently in the analysis. Future studies might want to consider integrating the market view and the more modern network view of the internationalization. Also, it is important to examine the internationalization of SMEs' in other OECD countries and compare the results. Furthermore, SMEs in 
developing countries should be investigated to identify, if the same conditions/requirements apply to them. This is of high importance due to the significant role that can be played by SMEs in the economies and in societies at large, and in those of the developing countries, in particular.

\section{References}

Acs, Z. J., \& Terjesen, S. (2013). Born local: toward a theory of new venture's choice of internationalization . Small Business Economics, 41(3), 521-535. https://doi.org/10.1007/s11187-012-9446-8

Acs, Z. J., Szerb, L., \& Autio, E. (2016). The global entrepreneurship and development index. In Global Entrepreneurship and Development Index 2015 (pp. 11-31). Springer International Publishing. https://doi.org/10.1007/978-3-319-26730-2_2

Adams, J., Khan, A \& Raeside, R., (2014) 'Research Methods for Business \& Social Science Students'-( $2^{\text {nd }}$ ed.) SAGE International Publishing, ISBN 978-81-321-1366-9.

Adler, N. (1983). Cross-Cultural Management Research: The Ostrich and the Trend. The Academy of Management Review, 8(2), 226-232.

Ang, S., \& Inkpen, A. C. (2008). Cultural intelligence and offshore outsourcing success: A framework of firm-level intercultural capability. Decision Sciences, 39(3), 337-358. https://doi.org/10.1111/j.1540-5915.2008.00195.x

Ang, S., Livermore, D., \& Van Dyne, L. (2010). Cultural Intelligence: A Pathway for Leading in a Rapidly Globalizing World. In M. \&. Hannum, Leading across Differences (pp. 131 - 138). San Francisco: Pfeiffer.

Ang, S., Van Dyne, L., Koh, C., Ng, K. Y., Templer, K. J., Tay, C., \& Chandrasekar, N. A. (2007). Cultural Intelligence: Its Measurement and Effects on Cultural Judgment and Decision Making, Cultural Adaptation and Task Performance. Management and Organi. Management and Organization Review, 3, 335-371. https://doi.org/10.1111/j.1740-8784.2007.00082.x

Ball, D. M. (2002). International Business: The Challenge of Global Competition (7th edition). McGraw Hill.

Baldegger, R. J., Wild, P., \& Morel, B. (2016). Swiss International Entrepreneurship Survey 2016: Results of the Study on Internationalization of Swiss SMEs, Freiburg: Postfinance Ltd and Bisnode D\&B Switzerland.

Barmeyer, C., \& Frankilin, P. (2016). Intercultural Management: A Case-Based Approach to Achieving Complementarity and Synergy. London: Palgrave-Macmillan. https://doi.org/10.1007/978-1-137-02738-2

Charles, M. (2006). LANGUAGE MATTERS IN GLOBAL COMMUNICATION.

Cortesi, E. (2010/2011). The internationalization of emerging market firms: motivations and approaches.

Crick, D. (2007). UK SMEs' motives for internationalizing: Differences between firms employing particular overseas market servicing strategies, Journal of International Entrepreneurship, 5, 11-23. https://doi.org/10.1007/s10843-007-0013-3

Crowne, K. A. (2008). What leads to cultural intelligence? Business Horizons, 51(5), 391-399. https://doi.org/10.1016/j.bushor.2008.03.010

Czinkota, M. R., Ronkainen, I. A., \& Moffett, M. H. (2002). International business. Harcourt College Publishers.

Doole, I., \& Lowe, R. (2008). International marketing strategy: analysis, development and implementation. Cengage Learning EMEA.

Du-Babcock, B. (2013). English as Business Lingua Franca: A comparative analysis of communication behavior and strategies in Asian and behavior and strategies in Asian and European contexts.

Dutta, S., Lanvin, B., \& Wunsch-Vincent, S. (2015). The Global Innovation Index 2016 effective innovation policies for development.

Earley, P. C., \& Ang, S. (2003). Cultural intelligence: Individual interactions across cultures. Stanford University Press.

Ehrenreich, S. (2010). English as a Business Lingua Franca in a German Multinational Corporation: Meeting the Challenge. Journal of Business Communication. https://doi.org/10.1177/0021943610377303

Eidgenossenschaft, S. (2017, July 2). Swiss Economy - Facts and Figures. Retrieved from About Switzerland: https://www.eda.admin.ch/aboutswitzerland/en/home.html

Evans, S. (2010). Business as usual: The use of English in the professional world in Hong kong. English for specific purposes. https://doi.org/10.1016/j.esp.2009.11.005 
Fakhreldin, H. (2011). The effect of cultural intelligence on employee performance in international hospitality industries: a case from the hotel Sector in Egypt. International Journal of Business and Public Administration, 8(2), 1-19.

Foreman-Peck, J., \& Zhou, P. (2015). Firm-level Evidence for the Language Investment Effect on SME Exporters. Scottish Journal of Political Economy. https://doi.org/10.1111/sjpe.12072

Garcia, L. (2009). European Markets as Challenges or Opportunities for Mexican SMEs' Internationalization: A Critical Analysis of Globalization. Perspectives on Global Development and Technology, 8, 372-398. https://doi.org/10.1163/156914909X423935

Gunnarsson, C. (2011). Value creation and loyalty in exchange relationships: a dynamic perspective. Örebro universitet (Doctoral dissertation).

Hurmerinta, L., Nummela, N., \& Paavilainen-Ma"ntyma"ki, E. (2015). Opening and closing doors: The role of language in international opportunity recognition and exploitation. International Business Review. https://doi.org/10.1016/j.ibusrev.2015.04.010

Jakl, M., \& Volery, T. (2006). Chancen und Problemfelder der Internationalisierung für KMU-eine internationale Betrachtung. In N. Kailer, \& H. Pernsteiner, Wachstumsmanagment fuer Mittel- und Kleinbetriebe: Eintrittschritte in die neuen EU-Maerkte . Berlin: Erisch Schmidt Verlag.

Kalinic, I., \& Forza, C. (2012). Rapid internationalization of traditional SMEs: Between gradualist models and born globals. International Business Review, 21(4), 694-707. https://doi.org/10.1016/j.ibusrev.2011.08.002

Kamakura, W. A., Ramón-Jerónimo, M. A., \& Gravel, J. D. (2012). A dynamic perspective to the internationalization of small-medium enterprises. Journal of the Academy of Marketing Science, 40(2), 236-251. https://doi.org/10.1007/s11747-011-0267-0

Kankaanranta, A., \& Louhiala-Salminen, L. (2013). "What language does global business speak?" - The concept and development of BELF.

Kelley, D. J., Singer, S., \& Herrington, M. (2012). The global entrepreneurship monitor: 2011 Global Report. GEM. GEM. Retrieved July 12, 2016.

Lakew , Y. D., \& Chiloane-Tsoka, G. (2015). Internationalisation Barriers of Small and Medium-sized Manufacturing Enterprises in Ethiopia: Leather and Leather Products Industry in Focus. International Journal of Business and Economic Development, 3(3), 68-80.

Lloyd-Reason, L., Ibeh, K., \& Deprey, B. (2009). Top Barriers and Drivers to SME Internationalization. OECD.

Lohmann, J. (2011). Do Language Barriers Affect Trade. Economics Letters. https://doi.org/10.1016/j.econlet.2010.10.023

London, K. (2010). Multi-Market Industrial Organizational Economic Models for the Internationalization Process by Small and Medium Enterprise Construction Design Service Firms. Architecture Engineering and Design, 6(B), 132-152. https://doi.org/10.3763/aedm.2009.0111

Masum, M. I., \& Fernandez, A. (2008). Internationalization Process of SMEs: Strategies and Methods. Mälardalen University.

McCusker, K., \& Gunaydin, S. (2014). Research using qualitative, quantitative and mixed methods and choice based research. Perfusion, 30(7), 537-542. https://doi.org/10.1177/0267659114559116

McDougall, P. P., \& Oviatt, B.M. (2000). International Entrepreneurship: the intersection of two research paths. Academy of Management Journal, 43(5), 902-906.

Moen, Ø., \& Servais, P. (2002). Born global or gradual global? Examining the export behavior of small and medium-sized enterprises. Journal of international marketing, 10(3), 49-72. https://doi.org/10.1509/jimk.10.3.49.19540

Mor, S., Morris, M. W., \& Joh, J. (2013). Identifying and training adaptive cross-cultural management skills: The crucial role of cultural metacognition. Academy of Management Learning \& Education, 12(3), 453-475. https://doi.org/10.5465/amle.2012.0202

Mura, L. G. (2011). An Analysis of Business Internationalization Models. Studia Universitatis Babes-Bolyai, 56(2), 16.

NG, K. Y., \& Earley, P. C. (2006). Culture+Intelligence: Old Constructs, New Frontiers. Group \& Organization Management, 31(1), 4-19. https://doi.org/10.1177/1059601105275251 
NG, K. Y., Dyne, L. V., \& Ang, S. (2009). Capability for Global Leader Development. From Experience to Experimental Learning : Cultural Intelligence as a Learning Academy of Mangement Learning and Education, 8(4), 511-526.

OECD. (2004). Promoting Entrepreneurship and Innovative SMEs in a Global Economy. In E. S. Report (Ed.), Second OECD Conference of Ministers Responsible for SMEs. Istanbul: OECD.

OECD. (2009). Top Barriers and Drivers to SME Internationalization Report. OECD Publishing.

OECD, P. A. (2000). Small and Medium-sized Enterprises: Local Strength - Global Reach. OECD.

Omer, N., Burg, E., Peters, R., \& Visser, K. (2015). Internationalization as a "Work-Around" Strategy: How going Abroad can help SMEs overcome local Constraints. Journal of Developmental Entrepreneurship, 2O(2), 1-22. https://doi.org/10.1142/S1084946715500119

Onkelinx, J., \& Sleuwaegen, L. (2008). INTERNATIONALIZATION OF SMEs. Flanders DC.

Ross, A., Adams, J. \& Crossan, K. (2015). Entrepreneurship and the spatial context: A panel data study into regional determinants of small growing firms in Scotland. Local Economy, 30(6), 672-688. https://doi.org/10.1177/0269094215600135

Ruzzier, M., Antoncic, B., Hisrich, R.D. (2007). The internationalization of SMEs: developing and testing a multi-dimensional measure on Slovenian firms. Entrepreneurship and Regional Development, 19(2), 161-183. https://doi.org/10.1080/08985620601137646

Schmiele, C. R. (2009). Drivers and Effects of Internationalizing Innovation by SMEs. Journal of Knowledge Management, 7(2), 18-61.

Sha, S. (2006). An investigation into problems facing small-to-medium sized enterprises in achieving growth in the Eastern Cape: Enhancing the strategy for developing small growth potential firms in the Eastern Cape. (N.-C. a. Projects, Ed.) Retrieved May 28, 2017, from National Research Foundation: http://hdl.handle.net/20.500.11892/22070

Sleuwaegen, L., \& Onkelinx, J. (2014). International commitment, post-entry growth and survival of international new ventures. Journal of Business Venturing, 29(1), 106-120. https://doi.org/10.1016/j.jbusvent.2013.01.001

Spencer-Oatey, H., \& Franklin, P. (2010). Intercultural Interaction: A Multi-disciplinary Approach to Intercultural Communication. London: Palgrave-Macmillan.

Syed, A., Shaikh, K., Mehmood, T., Afridi, T., \& Shaikh, F. (2011). Impact of Globalization on SMEs Export Business and Econmoy of Pakistan by using CGE Model. Asian Social Science, 7(9), 52-64. https://doi.org/10.5539/ass.v7n9p52

The Small and Medium Enterprises Policy Development Project. (2003). Profile of M/SMEs in Egypt. Cairo: Ministry of Foreign Trade. Retrieved 2016

Udomkit, N., \& Schreier, C. (2015). The Roles of Intercultural Competency, and the Openness for Intuition of Swiss and Thai SMEs in the Interntionalization Decision Making. 5th Annual Interntioal Conference on Business Strategy and Asian Economic Transformation (Biz Strategy 2015) (pp. 31-36). Singapore: GSTF.

Valdimirov, Z., Simeonova-Ganeva, R., \& Ganev, K. (2013). Significance of globalization-specific factors for SME competitiveness: a concptual model and an emperical test. Business Systems Review, 2(3), 1-25.

Van Dyne, L., Ang, S., \& Koh, C. (2008). Developing and validating the CQS . In S. Ang, \& L. Van Dyne, Handbook on Cultural Intelligence: Theory, Measurement and Applications (pp. 16 - 38). New York: Sharpe.

Wambui, N. N. (2013). Factors Influencig the Internationalisation of Small and Medium Enterprises (SMEs): A case study of Handicrafts in Kenya. 3.

Wild, J. J. (2014). International Business. New Jersey: Pearson Education Limited.

Wilson, K. (2006). Encouraging the Internationalisation of SMEs. OECD Papers, 6(12), 43-66.

Yilmaz, K. (2013). Comparison of Quantitative and Qualitative Research Traditions: epistemological, theoretical, and metholodological differences. Eurpopean Journal of Education, 48(2), 311-325. https://doi.org/10.1111/ejed.12014

Yuhua, B. Z. (2015). SME Internationalization and Measurement . APEC Policy Support Unit. 
Zhu, Y., Wittmann, X., \& Peng, M. W. (2012). Institution-based barriers to innovation in SMEs in China. Asia Pacific Journal of Management, 29(4), 1131-1142. https://doi.org/10.1007/s10490-011-9263-7

\section{Copyrights}

Copyright for this article is retained by the author(s), with first publication rights granted to the journal.

This is an open-access article distributed under the terms and conditions of the Creative Commons Attribution license (http://creativecommons.org/licenses/by/4.0/). 